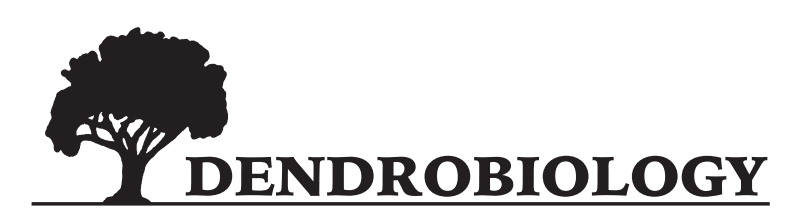

2019, vol. 82, 8-16

http://dx.doi.org/10.12657/denbio.082.002

\author{
Krystyna Boratyńska, Dominik Tomaszewski, Josep M. Montserrat, \\ Stawomir Marek, Adam Boratyński*
}

\title{
Taxonomic position of Pinus ceciliae (Pinaceae) endemic for Balearic Islands as revealed on needle characteristics
}

Received: 6 September 2019; Accepted: 26 November 2019

\begin{abstract}
The Cecilian pine (Pinus ceciliae) is endemic to Balearic islands (Spain). It is a small taxon, sometimes treated as synonym of Aleppo pine (P. halepensis), to which is closely related, differing mainly with dense crown shape and upright branches. The other characteristics, which differ between $P$. ceciliae and $P$. halepensis concern the cone scale and needle length only. We examined biometrically needles of Cecilian pine from Mallorca (5 tress) and Menorca (9 trees) islands, and compared them to Aleppo pine populations represented by 30 trees from each island. Each tree was represented by 5 needles, and they were studied with respect to 17 morphological and anatomical characteristics. We detected that needles of the Cecilian pine were smaller, but only when compared to the Aleppo pine from the same island. In general, this difference was also observed in the number of resin canals, number of stomata and stomatal rows. Interestingly, the proportions of the needle dimensions pattern were similar in both taxa. In conclusion we stated the results support the taxonomic rank of Cecilian pine as a variety, Pinus halepensis var. ceciliae (Llorens \& L.Llorens) L.Llorens, Fl. Països Catalans, 1: 197 (1984).
\end{abstract}

Keywords: biometry, discrimination analysis, Pinus halepensis, Principal Component Analysis

Addresses: K. Boratyńska, Institute of Dendrology, Polish Academy of Sciences, Parkowa 5, 62-035 Kórnik, e-mail: borkrys@man.poznan.pl

A. Boratyński, Institute of Dendrology, Polish Academy of Sciences, Parkowa 5, 62-035 Kórnik, e-mail: borata@man.poznan.pl

D. Tomaszewski, Institute of Dendrology, Polish Academy of Sciences, Parkowa 5, 62-035 Kórnik, e-mail:dominito@man.poznan.pl

Jose M. Montserrat, Jardin Botanico de Barcelona, Parc de Montjuïc, Dr. Font i Quer 2, 08038 Barcelona, e-mail: jmmontserrat@ibb.csic.es

S. Marek, Żabikowska street, 62-030 Luboń, Poland

*corresponding author

\section{Introduction}

Pinus ceciliae Llorens \& L.Llorens (1984: Folia Bot. Misc. 1984, 4: 55) (Pinaceae Spreng. ex F.Rudolphi, nom. cons.) was described as a species by Antoni and
Lleonard Llorens in 1972 (Llorens \& Llorens, 1972; Llorens L., 1984), but their taxonomic range has been reduced to the variety of Aleppo pine P. halepensis Mill. var. ceciliae (Llorens \& L.Llorens) L.Llorens (Llorens, 1979; Rosselló et al., 1992). The characteristics that 
distinguish the Cecilian pine specimens from typical $P$. halepensis are: 1) upright branches arranged at an angle of approximately $15^{\circ}$, which results in the formation of a narrow tree crown, and 2) smaller cones compared to $P$. halepensis, with convex scale apophysis (Llorens \& Llorens, 1972; Llorens, 1979, 1984; Laguna Lumbreras, 2000; Núñez Vázquez, 2013a,b). In addition, needles of the Cecilian pine are shorter (Fig. 1), a lighter green and its wood is softer compared to typical $P$. halepensis (Llorens, 1979; Núñez Vázques, 2013a,b).

The crown shape of Cecilian pine resembles a pyramidal or compact form of $P$. nigra J.F. Arnold and P. brutia Ten., reported from Anatolia (see Krüssmann, 1972; Vidaković, 1991; Yücel, 1997; Yaltirik \& Boydak, 2000; Boydak, 2001; Tosun, 2003; Ferrer \&
Laguna Lumbreras, 2010). However, the systematic status of the forms mentioned above has yet to be fully accepted, and they were treated as synonyms of $P$. nigra species or typical subspecies of $P$. brutia (Frankis, 2000). The status of $P$. ceciliae or P. halepensis var. ceciliae is unclear and the taxon name has been included in P. halepensis (Amaral Franco, 1986; Farjon, 2017). Lately, Cecilian pine was proposed as restricted, local taxon with the variety rank, known only from Balearic Islands (Bolòs \& Vigo, 1984; Rosselló et al., 1992; Rosselló \& Sáez, 2000).

The resin of the Aleppo pine has been used for production of tar by dry distilling its wood, a practice performed in the western Mediterranean since the Neolithic period (Orengo et al., 2013). Tar was indispensable for waterproofing objects like boats, shoe

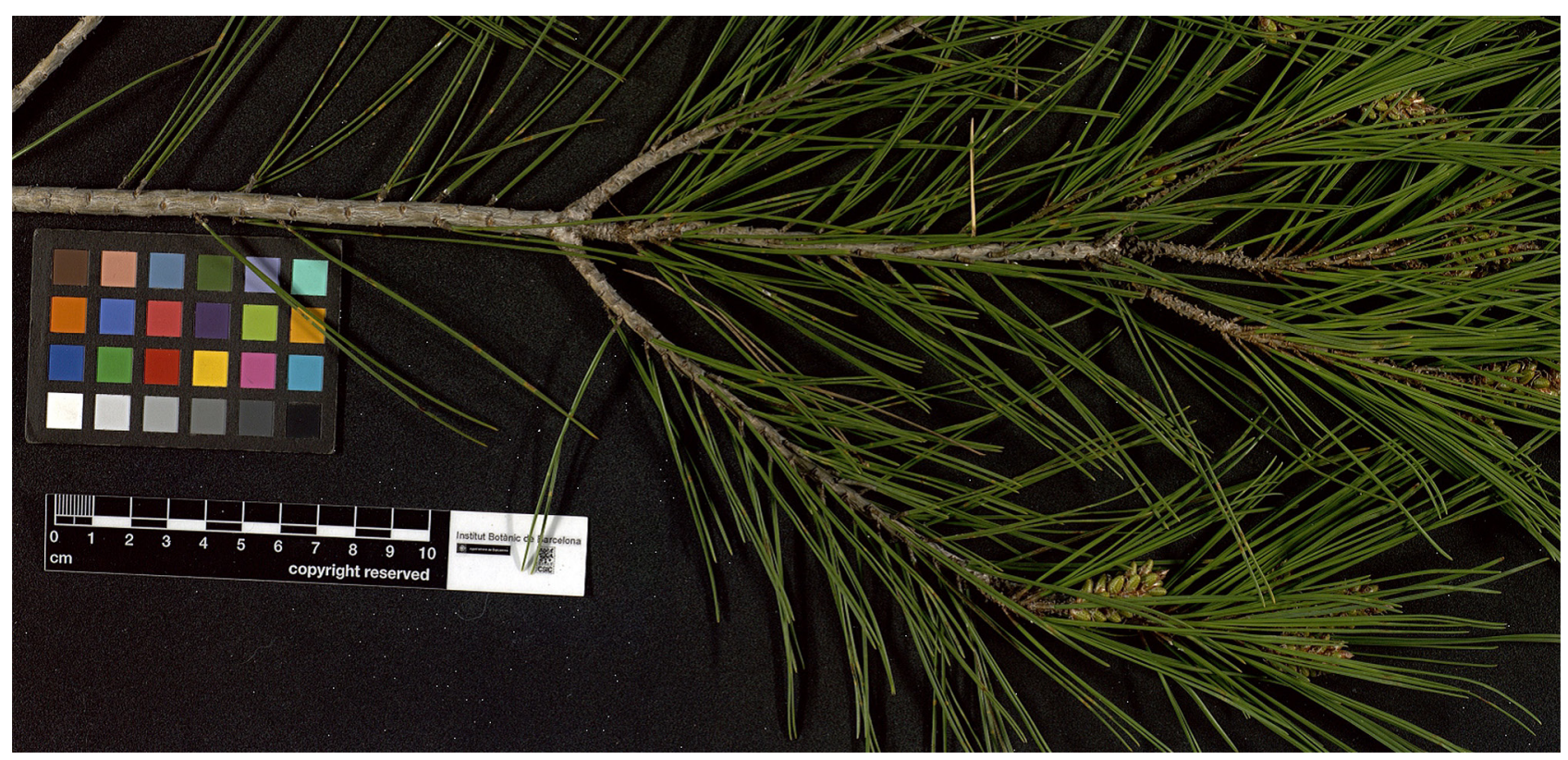

Fig. 1. Twigs of Pinus halepensis (up) and $P$. ceciliae (down) from the Barcelona Botanic Garden (photo J.M. Montserrat)

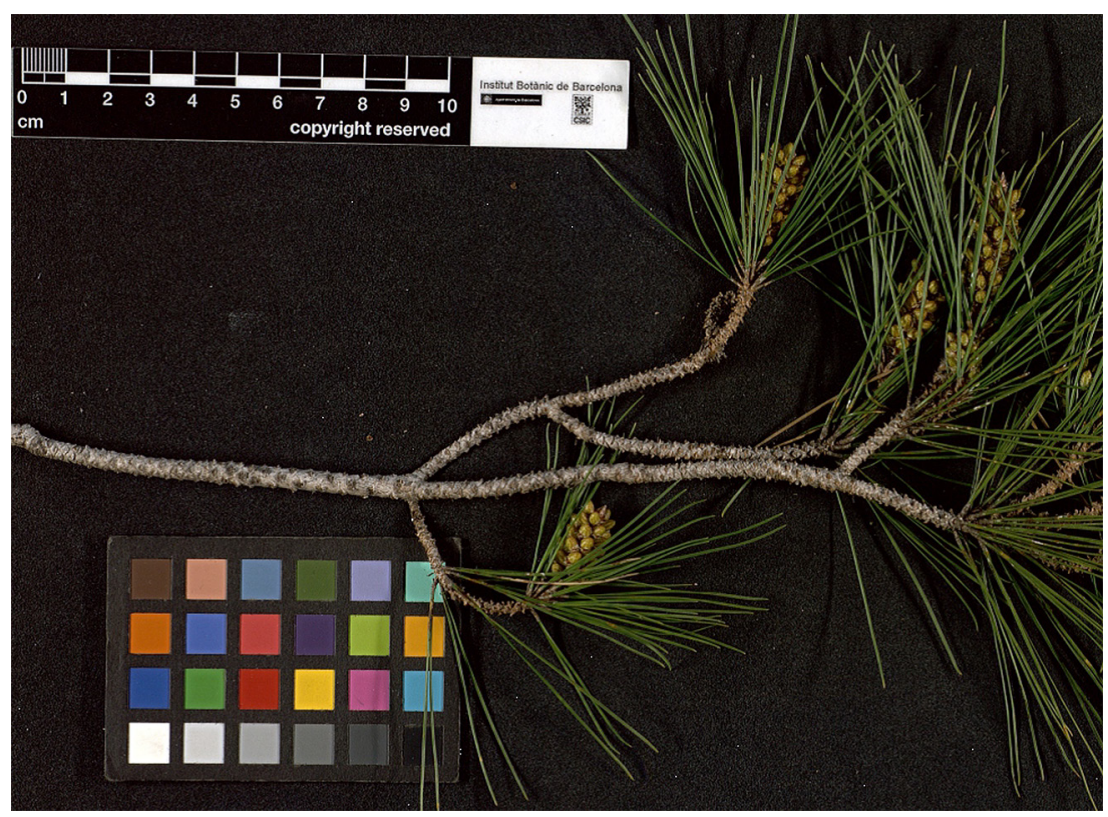


soles, water-resistant tools, among others. The resin-rich pines were also used to illuminate the streets before the introduction of modern street lamps.

A pine tree selected for its greater quantity of resin is easy to cut because of its softer wood (Llorens, 1979), which possibly grows faster and seems to be a good choice for tar production. It should be kept in mind that in the Balearic Islands, there are few tree species available, and in the past, most of craftworks, house and boat buildings and woodworks were made using materials obtained from local resources. Locally, this pine (Menorca, Pere Fraga, pers. comm.) is known as 'pi teier', which means resinous pine and is also known by the carpenters of Ciutadella (Menorca).

The Cecilian pine has been reported to be from Mallorca, Menorca, Ibiza and Cabrera (Núñez Vázquez, 2013a,b). It grows there as single trees dispersed among P. halepensis forests (Rosselló et al., 1992) mainly on private terrains. Currently, P. ceciliae has been reported in about 100 natural localities of (Núñez Vázquez, 2007, 2008, 2013a,b), and 160 places where it was planted. The relatively low number of localities and individuals in particular localities put this taxon among endangered taxa. Currently it is protected as a species 'of special interest' ( $\mathrm{CAB}$, 1992). Urbanisation is cited as a factor which puts it at risk of extinction, but frequent fires and the general absence of seedlings and saplings are mentioned as well (Núñez Vázquez, 2008, 2013a).

The known differences between $P$. ceciliae and $P$. halepensis are connected mainly with crown shape (e.g. López Gonzalez, 2001), but field observations have also showed that the leaf longevity on $P$. ceciliae was always less than two years, while on $P$. halepensis functional needles were observed in 2-year-old and even older dolichoblasts (Fig. 1). The detailed needle morphology and anatomy, however, have not been studied. Thus, the aim of this study was to compare the needle morphological and anatomical characteristics of the Cecilian pine with typical P. halepensis, using biometrical methods and statistical analyses. We expected to detect the needle characters, which could support the distinctiveness of Cecilian pine and support their taxonomic position as a variety.

\section{Material and methods}

\section{Material collection}

For the present study, we provisionally used the name $P$. ceciliae, and their taxonomic status was not presumed. The study area included two localities of this taxon, one from Mallorca and one from Menorca (Table 1). The sampling was conducted on 20 and 21 September 2004 in degraded P. halepensis forest communities on the limestone rock or on the substratum developed from limestone. The Cecilian pine did not form compact stands. Their individuals were dispersed in the forest of typical Aleppo pine.

Five two-year-old dwarf shoots were gathered from the sunny side of a crown of five trees in Mallorca and nine in Menorca. Each tree was represented by five needles, each needle taken from different dwarf shoots. P. ceciliae was characterised by data from 70 needles. For comparison, two populations of typical forms of $P$. halepensis were sampled from the same places. Each sample consisted of 150 needles taken from 30 individuals ( 5 needles per individual) (Table 1). The needle length was measured immediately after sampling. Subsequently, the needles were preserved in $70 \%$ alcohol and kept in a fridge until further preparations were made (Boratyńska \& Bobowicz, 2000, 2001).

\section{Analysed characteristics}

The needle preparation methods, the set of characteristics analysed and measurement methods were adopted from investigations on Mediterranean pine and fir species (Boratyńska \& Bobowicz, 2000, 2001; Bagci \& Babaç, 2003; Jasińska et al., 2014; Boratyńska et al., 2015). Finally, 12 needle characteristics were measured and/or evaluated, and an additional five resulted from recalculations (Table 2).

The number of stomata rows and stomata on a $2 \mathrm{~mm}$ long section from the central part of a needle (SRC, SRF, SNC and SNF in Table 2) were counted under a stereo microscope at magnification of $40 \times$. Measurements of the anatomical characteristics (NW, NT, RC, WE, TE, TH and DVB in Table 2) were

Table 1. Plant material of Pinus ceciliae (C) and P. halepensis (H) from Mallorca (MA) and Menorca (ME)

\begin{tabular}{|c|c|c|c|c|c|c|}
\hline Taxon & Code & Location & Latitude $\left[{ }^{\circ}\right] \mathrm{N}$ & Longitude $\left[{ }^{\circ}\right] \mathrm{E}$ & Altitude $[\mathrm{m}]$ & Number of specimens (needles) \\
\hline \multirow[t]{5}{*}{ Pinus ceciliae } & CMA & Mallorca, $\mathrm{N}$ of Cala Pi & 39.4106 & 2.8544 & 77 & $5(25)$ \\
\hline & CME & Menorca, Sant Tomàs & 39.9124 & 4.0457 & 15 & $1(5)$ \\
\hline & & & 39.9193 & 4.0386 & 59 & $1(5)$ \\
\hline & & & 39.9140 & 4.0518 & 76 & $5(25)$ \\
\hline & & Es Migjorn Gran & 39.9406 & 4.0418 & 126 & $2(10)$ \\
\hline \multirow[t]{2}{*}{ Pinus halepensis } & HMA & Mallorca, $\mathrm{N}$ of Cala Pi & 39.4106 & 2.8544 & 77 & $30(150)$ \\
\hline & HME & Menorca, Sant Tomàs & 39.9140 & 4.0518 & 76 & $30(150)$ \\
\hline
\end{tabular}




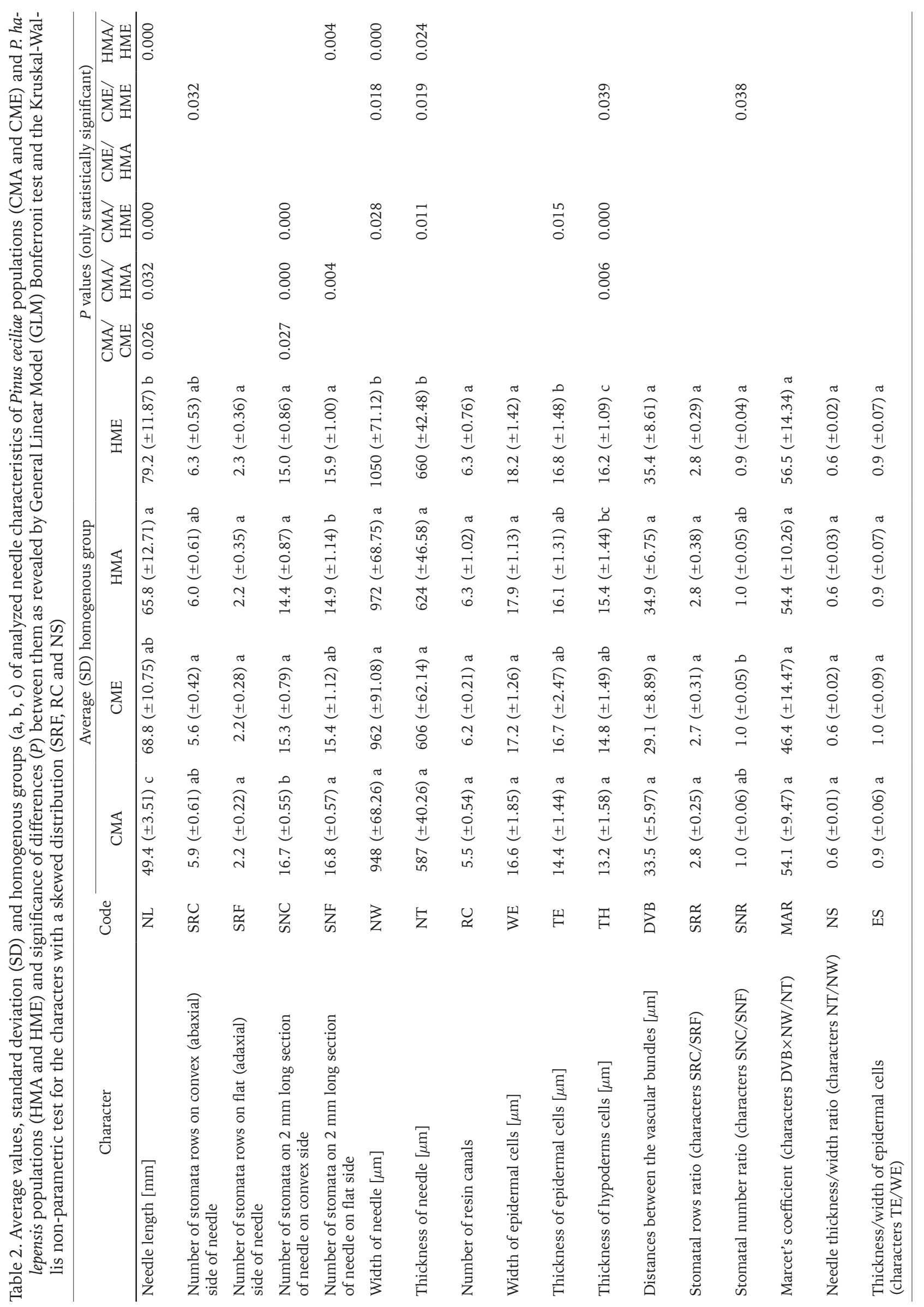


taken on the scaled photograms of cross sections from the central part of the needle. An optical microscope, Olympus BX 53-F with an Olympus DP27 camera and cellSens Standard software were used for the measurements.

\section{Statistical analyses}

The normality of the frequency distribution of every character and the homoscedasticity of the variances were tested using Shapiro-Wilk's W-test and Brown-Forsythe's test, respectively. The data were standardised before multivariate statistical analyses (Zar, 1999) to avoid the possible influence of different characteristic types.

To evaluate significant differences between $P$. ceciliae and P. halepensis from Mallorca and Menorca (four groups), the General Linear Model (GLM) Bonferroni test for characters with normal distribution and non-parametric Kruskal-Wallis test for characters with skewed distribution were used. A discrimination function analysis with a forward stepwise model (FSDA) was applied to identify the discrimination power of each character and eliminate possible redundant ones, as well as to describe the relationships between $P$. ceciliae and $P$. halepensis and to detect differences between particular individuals of both taxa (Sokal \& Rohlf, 1995). Additionally, these relations were verified using Principal Component Analysis (PCA) and cluster analysis after the Ward method. The statistical analyses were carried out using STATISTICA v. 9 (StatSoft PL).

\section{Results}

Most of the characteristics had normal distributions, with only the three following traits exhibiting a skewed distribution: number of stomatal rows on the flat side of the needle, the number of resin canals and the needle thickness/width ratio (SRF, RC and NS, respectively). Some characters had non-homoscedastic variances, which caused the discrimination analyses results to be unreliable.

More than a half of the characters evaluated in this study differed among four sets of compared material. Pinus ceciliae differed significantly from $P$. halepensis in several needle characteristics, but the highest numbers of differences between the species were found in pairs from the same island (Table 2). On both islands, significant differences between compared taxa were found only in the thickness of hypodermis cells $(\mathrm{TH})$, which was greater in $P$. halepensis than in $P$. ceciliae and did not differ between populations of the second species. On Mallorca, the number of stomata (SNC and SNF) and hypodermis thickness (TH), and to a lesser degree needle length
(NL), revealed significantly lower values $(P \leq 0.05)$ in the needles of $P$. ceciliae than in $P$. halepensis. On Menorca, the number of stomatal rows on the convex needle side (SRC), needle width and thickness (NW, NT), thickness of hypodermis cells (TH) and stomatal number ratio (SNR) were all significantly different $(P \leq 0.05)$ between $P$. ceciliae and $P$. halepensis (Table 2), in which larger values were observed for the characters in P. halepensis.

Interestingly, the needles of $P$. ceciliae from Mallorca (CMA) were shorter and had a greater number of stomata on the convex side than the needles from Menorca $(\mathrm{CME})(P \leq 0.05)$. A larger number of characters differentiated the populations of $P$. halepensis from both islands, and generally values of the characters from Menorca were greater (Table 2).

The results also revealed small but significant differences between populations of $P$. ceciliae from Mallorca and Menorca, and relatively high between populations of $P$. halepensis from these islands (Table 2).

Of all of the characteristics evaluated the FSDA distinguished NL, SNC and TH as the distinguishing characteristics between $P$. ceciliae and $P$. halepensis with the highest power. SRF, SNF, NT, WE, TE, DVB, MAR and SRR were excluded from the analysis model. The first discriminant variable $\mathrm{U}_{1}$, responsible for about $63 \%$ of the total variation, was determined mostly by NL, TH, SNC, NW and SNR, while the second variable $U_{2}$, which covered nearly $27 \%$ of the total variation, was influenced mostly by SNC, NS and NW. Individuals of $P$. ceciliae from Mallorca appeared to be different from populations of $P$. halepensis and P. ceciliae from Menorca (Fig. 2). Pinus ceciliae individuals were dispersed among individuals of $P$. halepensis. The classification matrix also confirmed

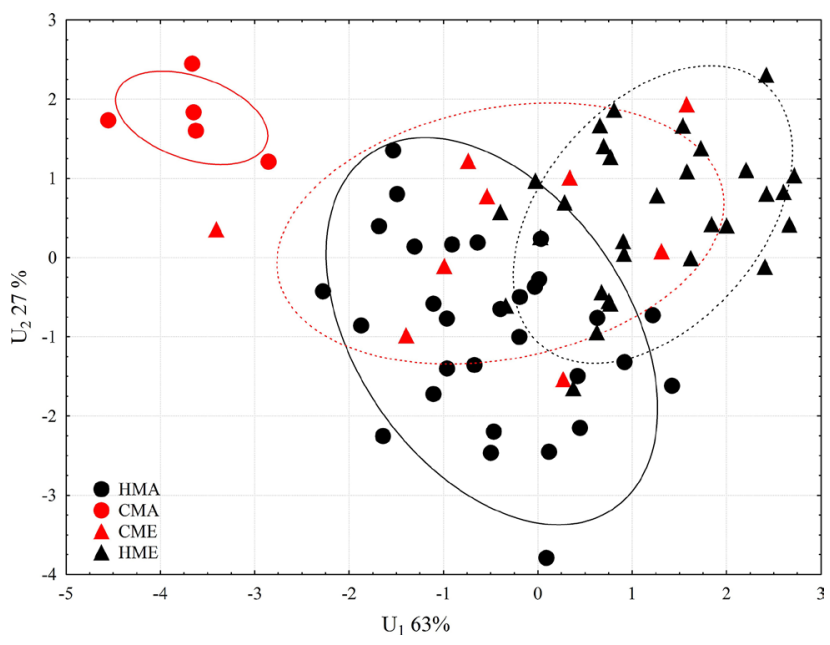

Fig. 2. Dispersion of $P$. ceciliae samples from Mallorca (CMA) and Menorca (CME) and P. halepensis samples from Mallorca (HMA) and Menorca (HME) (with 95\% confidence intervals for both compared taxa/islands) in 2-D space between two first discriminant variables responsible for nearly $90 \%$ of variation 


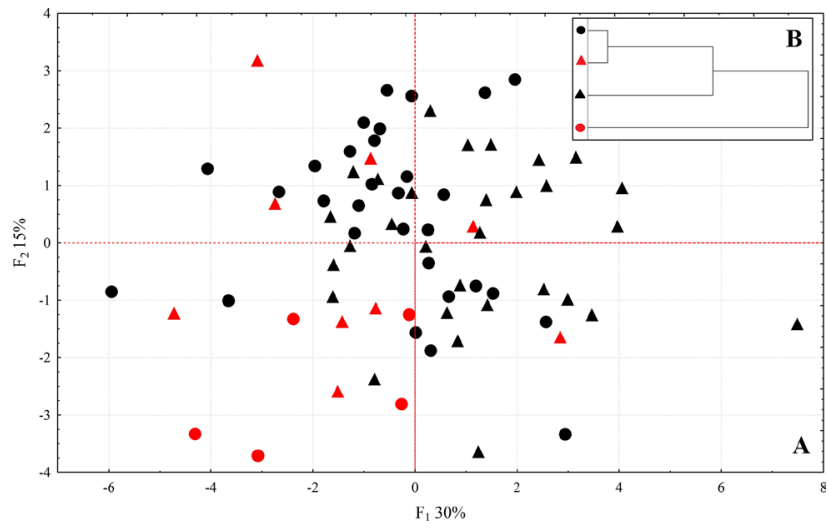

Fig. 3. Dispersion of individuals of Pinus ceciliae and P. halepensis in the space between two first principal components of PCA (A) and clustering of populations of $P$. ceciliae and $P$. halepensis after the Ward method (B)

a close connection of the Menorcan population of $P$. ceciliae to $P$. halepensis. Surprisingly, the population of $P$. ceciliae from Menorca and $P$. halepensis from Mallorca appeared to be the closest with a relatively small, but still significant square Mahalanobis' distance value of $3.8(P=0.013)$. The remaining square of Mahalanobis' distance combinations between populations were significantly large, with the greatest values between $P$. ceciliae from Mallorca and $P$. halepensis from Mallorca and Menorca, (17.5 and 25.5, respectively).

The dispersion of individuals between the first two principal components and clustering of populations showed similar results (Fig. 3A, B). Both analyses confirmed distinctiveness of $P$. ceciliae from Mallorca, while all individuals (except one) representing this taxon from Menorca, intermingled with individuals of typical $P$. halepensis, placed at the margin of this species variation space (Fig. 3A).

\section{Discussion}

The Pinus ceciliae description was based on a limited number of specimens from Mallorca. It was described as a tree with a compact crown, needles shorter than that of typical $P$. halepensis and smaller cones with protuberant umbo on cone scales (Llorens \& Llorens, 1972; Llorens, 1979; Núñez Vázquez, 2007, 2013a,b). Our data confirmed P. ceciliae individuals from Mallorca have a significantly smaller needle length (NL), but not individuals from Menorca, which have shorter (insignificantly) needles compared to the local Menorcan population of P. halepensis. At the same time, the needles from Menorcan individuals of $P$. ceciliae are longer (insignificantly) than needles of Mallorcan P. halepensis. This finding could indicate that needles of the P. ceciliae are shorter than $P$. halepensis needles, only on the same island.
The needle length of $P$. halepensis needles varies from about 60 to $120 \mathrm{~mm}$ (Coode \& Cullen, 1965; Werker \& Fahn, 1969; Meikle, 1977; Boulli et al., 2001; García Esteban et al., 2010), sometimes even up to $150 \mathrm{~mm}$ (Amaral Franco, 1986). In that context, needles from Mallorca appeared to be relatively short, while those from Menorca were also small, but closer to reported values (Table 2). In comparison with the data from the whole geographic range of $P$. halepensis, the needles of P. ceciliae are shorter on Mallorca, while on Menorca, the values resembled values reported from northern Morocco (Boulli et al., 2001, Table 2).

The needle length positively correlated with the altitude of the Atlas Mountains of Morocco (Boulli et al., 2001). This implicates a possible influence of environmental conditions, such as high temperatures, drought and low level of precipitation during vegetation period in the lowest locations. In our study, the specimens from both $P$. ceciliae and $P$. halepensis came from low locations, but the conditions on the Mallorca could have worsened as a result of human influence, as the island is highly urbanised.

Regarding other characteristics, the needle width (NW) for P. halepensis has been reported to vary from 0.7 to $1.0 \mathrm{~mm}$ (Amaral Franco, 1986). Our data (Table 2), which were based on needle cross-section measurements, revealed widths that were generally around $1 \mathrm{~mm}$ and indicated slightly smaller values for $P$. ceciliae, but significant differences were found between two species only on the Menorca island. The same trend was observed for the needle thickness (NT).

The number of resin canals on the cross-section of the $P$. ceciliae needle varied between 4 and 8 , with an average of 5.8. The mean value for the number of resin canals was approximately $6.3(2-10)$ in $P$. halepensis. We found no difference in the number of resin canals between $P$. ceciliae and $P$. halepensis. The number of resin canals observed in our study is similar to that reported for $P$. halepensis from the central and western Mediterranean region (Vidaković, 1953; Werker \& Fahn, 1969; Kivimäenpää et al., 2010).

The thickness of hypodermis (TH) was significantly lower in the $P$. ceciliae needles compared to $P$. halepensis needles; however, this character also appeared to be useful for distinguishing between species when comparing material from the same island (Table 2). Such data have not been analysed until now; however, in P. halepensis, the hypodermis is composed of two or even three cell-layers (Vidaković, 1953, 1991). Vidaković $(1953,1991)$ found a relationship between the number of hypodermis layers and the number of resin canals in two types of $P$. halepensis on the Balkan Peninsula. The first type had needles with 4-8 resin canals and 1-2 layers of hypodermis cells, while the second type had a smaller number of resin 

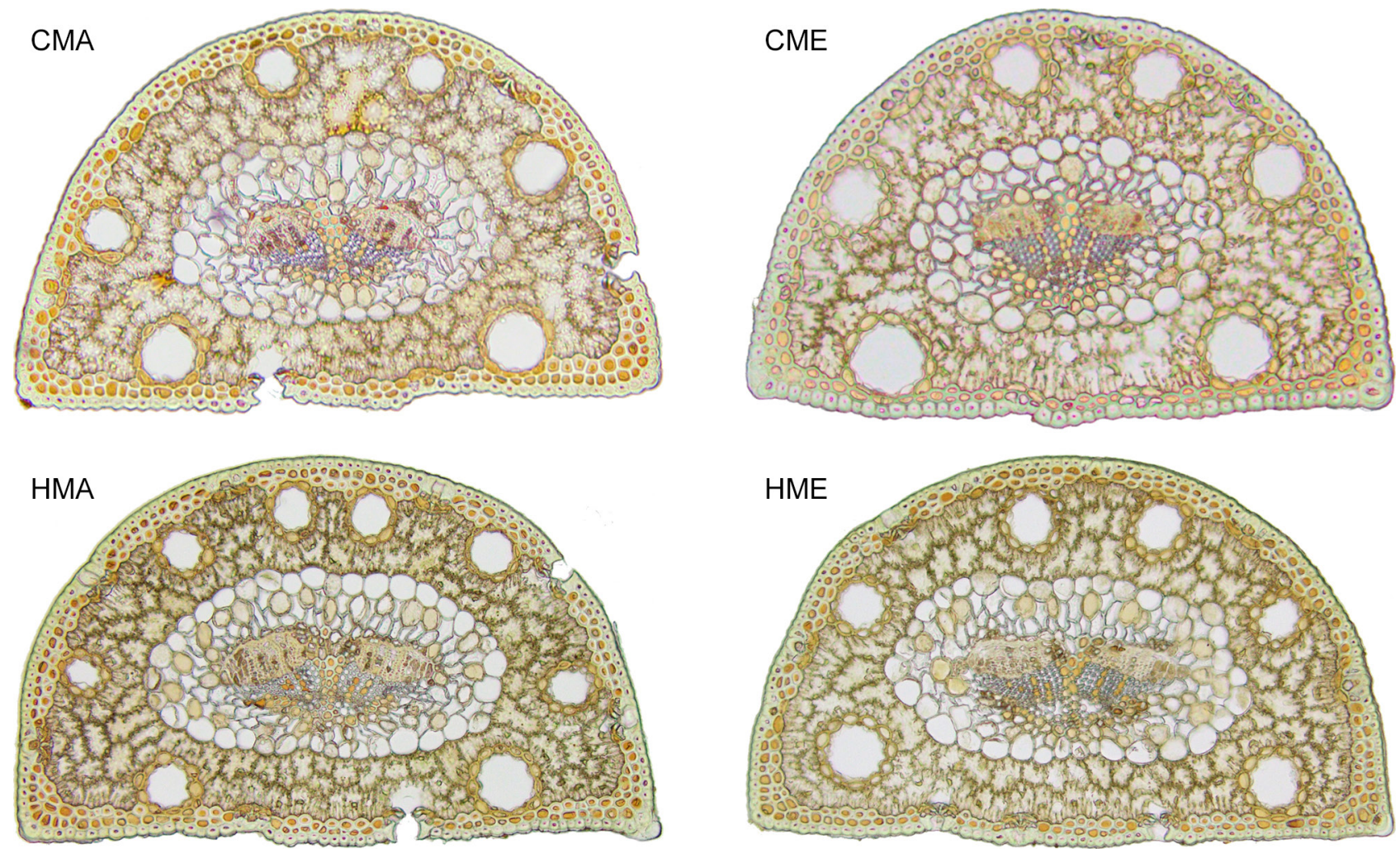

$\overline{200 \mu \mathrm{m}}$

Fig. 4. Cross-sections of needles of Pinus ceciliae and P. halepensis; acronyms as in Table 1 (photo K. Boratyńska)

canals (usually less than 4) and 2-4 hypodermis layers. Our data showed 1-2 layers of hypodermis cells, with some additional hypodermal cells in the corners of the needle cross-section in both $P$. ceciliae and $P$. halepensis (Fig. 4).

The number of stomata rows appeared to be significantly lower, only on the convex side (SRC) of the needles in $P$. ceciliae from Menorca than in the needles of $P$. halepensis, while in the Mallorcan populations of both taxa, the number of stomata rows was nearly the same (Table 2) - indicating an unstable nature of this characteristic. The number of stomata rows in the needles of $P$. halepensis had not been examined until now. However, the values observed in our study correspond, to some degree, with the number of stomata detected on the edges of the needle cross-section of $P$. halepensis from Mallorca (6) and Menorca (6.7) (Kivimäenpää et al., 2010).

The differences between $P$. halepensis and $P$. ceciliae were also found in the cone characteristics. Pinus ceciliae cones have scales with highly visible, procumbent apophyses, while the apophyses of $P$. halepensis cone scales are generally flat (Laguna Lumbreras, 2000). However, the cone of $P$. halepensis could have also scales with more procumbent, 'raised' apophyses (Vidaković, 1953, 1991; Ayari et al., 2014). We only had a few $P$. ceciliae cones, which made it impossible to perform a biometrical study. Despite this fact, it should be noted that the $P$. ceciliae cones had procumbent apophyses on their scales, while the apophyses of $P$. halepensis were flat.

In summary, significant differences were observed in the tree crowns of $P$. ceciliae and typical $P$. halepensis, but there were no substantial differences observed in the needles. Pinus ceciliae needles were smaller (NL, NW, NT), but only when compared with the samples from the same island. Additionally, in general, no significant differences were observed in the number of resin canals, stomata and stomatal rows. Interestingly, the proportions of the needle dimensions pattern are similar in both taxa. However, the study was performed on a relatively limited number of samples of $P$. ceciliae, and for that reason the presented results should be treated with some caution. Despite this limitation, in our opinion, Cecilia pine taxonomic rank is a variety, $P$. halepensis Mill. var. ceciliae (Llorens \& L.Llorens) L.Llorens ex O.Bolòs \& Vigo, Fl. Països Catalans, 1: 197 (1984), as proposed lately by Núñez Vázquez (2013a). The infraspecific position is proved by relatively low level of differences between this taxon and typical $P$. halepensis, local geographic distribution and probable origin from long lasting selection (Llorens, 1979).

Pinus halepensis var. ceciliae is an important element of $P$. halepensis variation and shall be conserved. Failure to recognition of the infraspecific taxa without 
critical evaluation using modern methods could lead to its' disappearance, and consequently, to loss of part of Mediterranean biodiversity (e.g. Hamilton \& Reichard, 1992; Dagnino et al., 2017). In this context, the conservation status of $P$. halepensis var ceciliae 'taxon of special interest' (CAB, 1992) is justified. Establishing of plantations to preserve the individuals representing this variety would be one of possible active protection.

\section{Nomeclatural note}

Pinus halepensis Mill. var. ceciliae (Llorens \& L. Llorens) L. Llorens ex O. Bolòs \& Vigo, Fl. Països Catalans, 1: 197 (1984)

\section{Homotypic Names:}

- Pinus ceciliae Llorens \& L.Llorens, Folia Bot. Misc. 4: 55 (1984), basion.

- Pinus halepensis var. ceciliae (Llorens \& L.Llorens) L.Llorens ex Rosselló, Cubas \& N.Torres, Candollea 47: 67 (1992), comb. superfl.

- Pinus halepensis Mill. var. ceciliae (Llorens \& L. Llorens) L. Llorens, Mediterranea, 3: 116 (1979), comb. inval.

- Pinus halepensis subsp. ceciliae (Llorens \& L.Llorens) Silba, J. Int. Conifer Preserv. Soc. 16: 22 (2009).

\section{Acknowledgments}

The study was financially supported by the Institute of Dendrology of the Polish Academy of Sciences (under statutory activity). Material collection was possible due to bilateral cooperation between Polish Academy of Sciences and Consejo Superior de Investigaciones Científicas.

\section{Literature}

Amaral Franco J, do (1986) Pinus L.: Flora iberica. Vol. 1. (ed. by S Castroviejo, M Laínz, G López González, P Montserrat, F Muñoz Garmendia, J Paiva \& L Villar) Real Jardín Botánico, Madrid, pp. 168-174.

Ayari A, Salah G \& Daniel M (2014) Seed and cone production patterns from seventy-nine provenances of Pinus halepensis Mill. across Tunisia forests. Global Journal of Botanical Science 2: 65-74.

Bagci E \& Babaç MT (2003) A morphometric and chemosystematic study on the Abies Miller (Fir) species in Turkey. Acta Botanica Gallica 150: 355367.

Bolòs O, de \& Vigo J (1984) Flora dels Països Catalans. Vol. 1. Editorial Barcino, Barcelona.
Boratyńska K, Sękiewicz K, Jasińska AK, Tomaszewski D, Iszkuło G, Ok T, Bou Dagher-Kharrat M \& Boratyński A (2015) Effect of geographic range discontinuity on taxonomic differentiation of Abies cilicica. Acta Societatis Botanicorum Poloniae 84: 419-430.

Boratyńska K \& Bobowicz MA (2000) Variability of Pinus uncinata Ramond ex DC as expressed in needle traits. Dendrobiology 45: 7-16.

Boratyńska K \& Bobowicz MA (2001) Pinus uncinata Ramond taxonomy based on needle characters. Plant Systematics and Evolution 227: 183-194.

Boulli A, Baaziz M \& M'Hirit O (2001) Polymorphism of natural populations of Pinus halepensis Mill. in Morocco as revealed by morphological characters. Euphytica 119: 309-316.

Boydak M (2001) A new variety of Pinus nigra J.F. Arnold subsp. pallasiana (Lamb.) Holmboe from Anatolia. Karaca Arboretum Magazine 6: 15-23.

CAB (Comunidad Autónoma de Baleares) (1992) Decreto 24/1992, de 12 de marzo 1992. Catálogo Balear de especies vegetales amenazadas. Butlletí Oficial de la Comunitat Autónoma de les Illes Balears 40/1992.

Coode MJE \& Cullen J (1965) Pinus L.: Flora of Turkey. Vol. 1. (ed. by PH Davis) Edinburgh University Press, Edinburgh, pp. 72-75.

Dagnino D, Minuto L \& Casazza G (2017) Divergence is not enough: the use of ecological niche models for the validation of taxon boundaries. Plant Biology 19: 1003-1011.

Farjon A (2017) A handbook of the world's conifers: Revised and updated edition. Brill, Leiden.

Ferrer Gallego PP \& Laguna Lumbreras E (2010) Sobre las variedades enanas de Pinus halepensis Mill. y P. pinea L. (Pinaceae). Toll Negre 12: 43-62.

Frankis MP (2000) Pinus L. (Pinaceae): Flora of Turkey and the East Aegean Islands, Supplement 2. (ed. by A Güner, N Özhatay, T Ekïm \& KHC Başer) Edinburgh University Press, Edinburgh, pp. 6-7.

García Esteban L, Martín JA, Palacios P, de, García Fernández F \& López R (2010) Adaptive anatomy of Pinus halepensis trees from different Mediterranean environments in Spain. Trees 24: 19-30.

Jasińska AK, Boratyńska K, Dering M, Sobierajska KI, Ok T, Romo A \& Boratyński A (2014) Distance between south-European and south-west Asiatic refugial areas involved morphological differentiation: Pinus sylvestris case study. Plant Systematics and Evolution 300: 1487-1502.

Hamilton CW \& Reichard SH (1992) Current practice in the use of subspecies, variety, and forma in the classification of wild plants. Taxon 41: 485498.

Kivimäenpää M, Sutinen S, Calatayud V \& Sanz MJ (2010) Visible and microscopic needle alterations 
of mature Aleppo pine (Pinus halepensis) trees growing on an ozone gradient in eastern Spain. Tree Physiology 30: 541-554.

Krüssmann G (1972) Handbuch der Nadelgehölze. Paul Parey, Berlin, Hamburg.

Laguna Lumbreras E (2000) Del nombre botánico de algunos grupos de especies cultivadas, plantadas o asilvestradas en el oriente Ibérico. II: Hedera, Pinus, Plectranthus. Flora Montiberica 15: 21-30.

Llorens A \& Llorens L (1972) Contribucinó al estudio de la flora balear. Bolletí de la Societat d'Història Natural de les Balears 17: 51-54.

Llorens L (1979) Nueva contribución al conocimiento de la flora balear. Mediterránea 3: 101-122.

Llorens L (1984) Notas floristicas Baleáricas. Folia Botanica Miscellanea 4: 55-58.

López González G (2001) Los árboles y arbustos de la Península Ibérica e Islas Baleares: Especies silvestres y las principales cultivadas. Mundi-Prensa, Madrid.

Meikle RD (1977) Flora of Cyprus. Royal Botanic Gardens, Kew.

Núñez Vázquez L (2007) Pinus halepensis var. ceciliae: Bioatlas. Palma: Consellaria de Medi Ambient, 2nd ed. Ficha de Bioatlas correspondiente a la especie Pinus halepensis var. ceciliae.

Núñez Vázquez L (2008) El plan de sanidad forestal del "pino cecilia" Pinus halepensis var. ceciliae (A. Llorens et Ll. Llorens, 1972) L. Llorens ex O.Bolos de las Islas Baleares, situation actual: V Jornades del Medi Ambient de les Illes Balears (ed. by GX Pons) Sociedad de Història Natural de les Balears, pp. 200-203.

Núñez Vázquez L (2013a) El Pinus halepensis var. ceciliae o Pino Cecilia, una variedad de pino español desconocido por los forestales. Sociedad Española de Ciencias Forestales. $6^{\circ}$ Congreso Forestal Español, Alava.
Núñez Vázquez L (2013b) Localizaciones conocidas del Pinus halepensis var. ceciliae o Pino Cecilia: VI Jornades de Medi Ambient de les Illes Balears (ed. by GX Pons, A Ginard \& D Vicens) Societat d'Història Natural de les Balears, pp. 184-186.

Orengo HA, Palet JM, Ejarque A, Miras Y \& Riera S (2013) Pitch production during the Roman period: an intensive mountain industry for a globalised economy? Antiquity 87: 802-814.

Rosselló JA, Cubas P \& Torres N (1992) An annotated check-list of the Balearic vascular flora. I. Pteridophyta-Coniferophytina. Candollea 47: 61-69.

Rosselló JA \& Sáez L (2000) Index Balearicum: An annotated check-list of the vascular plants described from the Balearic Islands. Collectanea Botanica 25: 3-192.

Sokal RR \& Rohlf FJ (1995) Biometry. 3rd ed. W. H. Freeman and Company, New York.

Tosun S (2003) The native distribution of compact forms of black pine (Pinus nigra J. F. Arnold), scots pine (P. sylvestris L.) and red pine (P. brutia Ten.) in Bolu province (Turkey). The Karaca Arboretum Magazine 7: 27-28.

Vidaković M (1953) Prilog poznavanju oblika vrste Pinus halepensis Mill. Šumarski List 1: 11-18.

Vidaković M (1991) Conifers: morphology and variation. Grafički Zavod Hrvatske, Croatia.

Werker E \& Fahn A (1969) Resin ducts of Pinus halepensis Mill. - their structure, development and pattern of arrangement. Botanical Journal of the Linnean Society 62: 379-411.

Yaltirik F \& Boydak M (2000) A new variety of Calabrian pine (Pinus brutia Ten.) from Anatolia. The Karaca Arboretum Magazine 5: 173-180.

Yücel E (1997) Pinus brutia Ten. var. agrophiotii Papaj. 'nin yeni bir yayılıș alanı ve bazı ekolojik özellikleri. The Karaca Arboretum Magazine 4: 25-28.

Zar JH (1999) Biostatistical analysis. 4th ed. Prenice-Hall, New Jersey. 